\title{
Jus tomat mampu menurunkan kolesterol tetapi tidak berefek pada tekanan darah
}

\section{Tomato juice can reduce cholesterol but does not effect blood}

\author{
pressure \\ Diyah Candra Anita \\ Universitas ‘Aisyiyah Yogyakarta, Jalan Siliwangi (Ring Road Barat) No. 63 Nogotirto, Gamping, Sleman, \\ Yogyakarta 55292, Indonesia \\ diyah.candra@gmail.com* \\ *corresponding author
}

Tanggal Submisi: 2 November 2019, Tanggal Penerimaan: 20 Desember 2019

\begin{abstract}
Abstrak
Tujuan dalam penelitian ini adalah untuk mengevaluasi perbedaan tekanan darah dan kadar kolesterol responden yang diberikan dan tidak diberikan jus tomat. Metode penelitian ini adalah eksperimen semu. Sampel yang digunakan 20 orang, dengan 10 orang kelompok kontrol dan 10 orang berikutnya kelompok perlakuan. Pemberian 200 cc jus tomat dilakukan selama 14 hari dan diberikan setiap pagi hari sebelum makan. Hasil penelitian menunjukkan terdapat perbedaan bermakna kadar kolesterol darah $(\mathrm{p}=0,006)$, namun tidak terdapat perbedaan bermakna tekanan darah baik sistolik $(\mathrm{p}=0,054)$ maupun diastolik $(\mathrm{p}=0,070)$ pada kelompok kontrol dan kelompok perlakuan setelah pemberian jus tomat 14 hari.
\end{abstract}

Kata kunci: tekanan darah; kolesterol darah; jus tomat

\begin{abstract}
The purpose of this study was to evaluate differences in blood pressure and cholesterol levels of respondents who were given and not given tomato juice. This research method is quasi-experimental. The sample used 20 people, with 10 people in the control group and the next 10 people in the treatment group. Giving $200 \mathrm{ccs}$ of tomato juice is done for 14 days and is offered every morning before eating. The results showed there were significant differences in blood cholesterol levels $(\mathrm{p}=0.006)$, but there were no significant differences in both systolic blood pressure $(p=0.054)$ and diastolic $(p=0.070)$ in the control group and the treatment group after 14 days of tomato juice administration.
\end{abstract}

Keywords: blood pressure; blood cholesterol; tomato juice

\section{PENDAHULUAN}

Aterosklerosis merupakan penyebab kematian utama laki-laki dan wanita di seluruh dunia. Aterosklerosis adalah suatu penyakit yang mengenai pembuluh darah arteri, yang diawali dengan pembentukan plak aterosklerotik pada dinding arteri, sehingga menyebabkan penebalan dinding dan penyempitan lumen. Aterosklerosis 
sering menimbulkan berbagai komplikasi, seperti stroke dan penyakit jantung koroner (Nasution, 2013).

Banyak faktor yang dapat menyebabkan aterosklerosis. Faktor risiko tersebut adalah faktor genetik, penyakit jantung koroner, stroke, penyakit pembuluh darah perifer, usia, kelamin pria, kebiasaan merokok, hiperkolesterol, hipertensi, obesitas, diabetes mellitus, kurang aktivitas fisik, dan menopause (Anwar, 2004). Hiperkolesterol pada darah mampu menyebabkan perkembangan aterosklerosis baik pada hewan maupun manusia, bahkan tanpa adanya faktor risiko yang lain (Samson, Mundkur, \& Kakkar, 2012).

Angka penderita hiperkolesterolemia semakin meningkat setiap tahunnya. Menurut penelitian, angka penderita hiperkolesterolemia di Indonesia mengalami peningkatan yaitu sebesar $13,4 \%$ menjadi $16,2 \%$ untuk wanita dan $11,4 \%$ menjadi $14,0 \%$ untuk pria. Pada tahun 2004, prevalensi hiperkolesterolemia di Indonesia mencapai 10,9\% dari total populasi penduduk (Anwar, 2008).

Menurut penelitian Seprianti (2011), kadar kolesterol yang tinggi khususnya pada pria, sangat berisiko terjadi peningkatan tekanan darah atau hipertensi. Penelitian yang dilakukan oleh Margarita et al., (2013) menyimpulkan bahwa menjaga kadar kolesterol total dalam batas normal merupakan salah satu upaya untuk mencegah hipertensi. Kadar kolesterol darah yang tinggi atau sering disebut hiperkolesterolemia cenderung dipengaruhi oleh gaya hidup yang salah. Gaya hidup tersebut antara lain pola makan yang tinggi kandungan lemak dan kolesterol, kurang mengkonsumsi makanan berserat (buah dan sayur), kebiasaan merokok, minum kopi, pola makan yang tidak teratur, stres emosional, dan jarang berolahraga (Nasution, 2013).

Sebagai salah satu bentuk pencegahan penyakit kardiovaskular yang berkelanjutan, maka pengendalian terhadap kadar kolesterol mutlak kita perlukan untuk mencapai derajat sehat. Rekomendasi kadar kolesterol total yang baik menurut American Heart Association (AHA) adalah kurang dari $200 \mathrm{mg} / \mathrm{dL}$, dan akan diklasifikasikan hiperkolesterol apabila kadarnya lebih dari $240 \mathrm{mg} / \mathrm{dL}$ (Palozza et al., 2012). Pengendalian kadar kolesterol dapat dilakukan dengan terapi farmakologi dan non-farmakologi guna mengurangi risiko berkembangnya aterosklerosis. Terapi farmakologi yang sering digunakan untuk menurunkan kadar kolesterol darah adalah statin dan niasin. Kedua obat tersebut mampu menghambat sintesis kolesterol, namun keduanya memiliki efek samping yang merugikan bagi tubuh. Statin dapat mengakibatkan miopati dan kerusakan hati (Palozza et al., 2012), sedangkan niasin dapat menimbulkan mual dan nyeri abdomen pada sebagian orang, serta meningkatkan kadar asam urat (Dwijayanti, 2011). Dikarenakan besarnya risiko akibat terapi farmakologi, maka diperlukan terapi lain yang murah, mudah, dan minim risiko untuk mengendalikan kadar kolesterol darah.

Salah satu zat yang mampu menghambat sintesis kolesterol adalah lycopene. Lycopene merupakan pigmen karotenoid alami yang paling banyak ditemukan pada tomat serta produk olahan tomat. Lycopene juga terdapat pada buah-buahan lainnya, seperti pepaya, semangka, jambu, dan jeruk, namun kadarnya tidak setinggi pada tomat (Palozza et al., 2012). Ried \& Fakler (2011) menyebutkan bahwa konsumsi tinggi lycopene dapat menurunkan risiko penyakit kardiovaskular, termasuk aterosklerosis, infark miokard, dan stroke. Mekanisme biokimia yang mendasari efek protective lycopene terhadap perkembangan penyakit kardiovaskular adalah menurunkan kandungan kolesterol-LDL (low density lipoprotein, bertindak sebagai antioksidan alami sehingga mampu mengurangi oksidasi lipid dan lipid peroksidase, mengatur 
respon inflamasi dengan mengurangi aktivitas sitokin yang terlibat dalam perkembangan penyakit kardiovaskular, dan menurunkan kadar kolesterol total (Navarro-González et al., 2014).

Lycopene merupakan agen hipokolesterolemik karena mampu memodulasi aktivitas enzim hydroxyl-3methylglutaryl-CoA reductase (HMGCR), yang terlibat dalam jalur biosintesis kolesterol. Penghambatan HMGCR yang dilakukan oleh lycopene menyerupai efek yang dilakukan oleh obat statin dalam menurunkan kadar kolesterol total (Navarro-González et al., 2014). Lycopene juga mampu meningkatkan pengambilan dan degradasi LDL oleh makrophag, dan dapat meningkatkan pengaturan reseptor LDL, sehingga kadar LDL dalam darah dapat berkurang (Preedy \& Waston, 2008).

Selain lycopene, buah tomat juga kaya akan senyawa fenolik, yaitu asam klorogenik, rutin, dan naringenik. Senyawa fenolik tersebut mampu menurunkan tekanan darah, menurunkan kolesterol total, menekan aktivitas sitokin pro-inflamasi, dan menekan aktivitas HMGCR (Navarro-González et al., 2014). Lycopene yang terkandung dalam tomat, mampu menjaga elastisitas tunika intima dan tunika media pembuluh darah sehingga mampu menurunkan peningkatan tekanan perifer yang menyebabkan hipertensi ( $\mathrm{Li} \& \mathrm{Xu}, 2013$ ). Mengingat manfaat akan kandungan tomat cukup banyak, maka konsumsi tomat secara teratur dipercaya mampu menurunkan tekanan darah dan kadar kolesterol dengan disertai efek samping yang minimal.

Tomat akan lebih mudah dikonsumsi jika diolah dalam bentuk jus, sehingga penyerapan tubuh terhadap tomat akan lebih mudah dan cepat. Tomat yang dibuat dalam bentuk jus akan lebih enak dikonsumsi jika ditambahkan madu sebagai pemanis alami. Madu merupakan bahan alami yang memiliki khasiat untuk menurunkan hiperglikemia, bilirubin, trigliserid, VLDL, dan LDL, serta mampu meningkatkan HDL dalam darah (Erejuwa, 2014).

Tujuan umum dalam penelitian ini adalah untuk mengevaluasi perbedaan tekanan darah dan kadar kolesterol total responden yang diberikan dan tidak diberikan jus tomat.

\section{METODE PENELITIAN}

Penelitian ini merupakan penelitian observasional analitik komparasi terhadap kadar kolesterol dan tekanan darah dengan penggunaan metode penelitian eksperimen semu. Pemberian jus tomat dibuat dari tomat sebanyak 200 gram yang dicuci bersih, lalu potong tomat menjadi beberapa bagian kemudian masukkan ke dalam blender, berikan 21 gram madu atau setara dengan 1 sendok makan dan tambahkan air sebanyak $125 \mathrm{cc}$, kemudian blender tomat tersebut. Dari $200 \mathrm{cc}$ jus tomat untuk sekali minum selama 2 minggu atau 14 hari (Anggraeni, Rosalina, \& Aniroh, 2014). Pemberian jus tomat dilakukan satu kali setiap pagi hari sebelum makan.

Pengukuran tekanan darah dilakukan pukul 06.00-07.00 WIB. Pengukuran kadar kolesterol sebelum dan sesudah pemberian jus tomat dengan menggunakan alat GCU digital merek Easytouch. Sebelum pengukuran, responden dianjurkan berpuasa selama 9 jam, mulai dari jam 22.00 sampai dengan 07.00 WIB. Pengukuran tekanan darah maupun kolesterol diukur pada hari ke-0 dan hari ke-15.

Populasi dalam penelitian ini adalah seluruh responden Dusun Ngrame Tamantirto Kasihan Bantul, yang berusia dewasa ( $>18$ tahun - 59 tahun) dan memiliki kadar kolesterol $>200 \mathrm{mg} / \mathrm{dL}$. Jumlah populasi adalah 20 orang. Metode pengambilan sampel dilakukan dengan metode total sampling, yang terbagi menjadi dua kelompok, 
yaitu 10 orang merupakan kelompok perlakuan dan 10 orang merupakan kelompok kontrol. Analisis hasil untuk penelitian ini menggunakan program statistik. Skala data yang digunakan adalah skala numerik yang disajikan dalam bentuk rerata \pm Standard Error of Mean (SEM). Sebelum analisis, dilakukan uji normalitas data terlebih dahulu. Data yang berdistribusi normal diuji dengan statistik parametrik.

Uji statistik independent t-test digunakan untuk mengetahui adanya perbedaan tekanan darah dan kadar kolesterol pada responden yang diberikan dan yang tidak diberikan jus tomat. Penelitian ini dilakukan di RT 02 Dusun IV Ngrame Tamantirto Kasihan Bantul Yogyakarta, pada tanggal 5-19 September 2016.

\section{HASIL DAN PEMBAHASAN}

Tabel 1. Karakteristik responden

\begin{tabular}{|c|c|c|c|}
\hline \multirow{2}{*}{ Karakteristik } & \multicolumn{2}{|c|}{ n (20) } & \multirow{2}{*}{ Presentase $(\%)$} \\
\hline & Kelompok Perlakuan & Kelompok Kontrol & \\
\hline \multicolumn{4}{|l|}{ Usia } \\
\hline 45-50 Tahun & 4 & 9 & 65,00 \\
\hline 51-55 Tahun & 6 & 1 & 35,00 \\
\hline \multicolumn{4}{|l|}{ Jenis Kelamin } \\
\hline Laki-laki & 2 & 7 & 40,00 \\
\hline Perempuan & 8 & 3 & 60,00 \\
\hline \multicolumn{4}{|l|}{ Pendidikan } \\
\hline Tidak Sekolah & 2 & 1 & 15,00 \\
\hline SD & 6 & 3 & 45,00 \\
\hline SMP & 3 & 1 & 20,00 \\
\hline SMA & 1 & 2 & 15,00 \\
\hline PT & 1 & - & 5,00 \\
\hline Total & 10 & 10 & 100,00 \\
\hline
\end{tabular}

Berdasarkan hasil penelitian (tabel 1) yang dilakukan di wilayah RT 02 Dusun IV Ngrame Tamantirto Kasihan Bantul Yogyakarta selama 14 hari, diketahui bahwa responden yang memiliki kadar kolesterol $>200 \mathrm{mg} / \mathrm{dL}$ banyak dialami pada usia 45-55 tahun yaitu sebanyak 13 orang (65\%). Menurut Info Datin Kemenkes (2013) pada usia tersebut mulai terjadi proses penuaan dan metabolisme menjadi lambat, sehingga dapat meningkatkan risiko penyakit jantung koroner.

Pada usia 45-55 tahun akan terjadi proses penuaan pembuluh darah. Faktor usia mempengaruhi kemunduran fungsi tubuh termasuk kekakuan pembuluh darah (mengkerut dan menua). Bertambahnya usia juga mempengaruhi penurunan fungsi hormon estrogen dan testosteron dalam mendistribusikan lemak, sehingga memungkinkan terjadinya penumpukan lemak dalam tubuh. Bahayanya jika penumpukan lemak ini menempel pada dinding pembuluh darah maka penimbunan ini akan mempersempit aliran darah, apalagi jika pembuluh darah telah menua. Kondisi ini akan mengakibatkan penyumbatan pembuluh darah jantung dan penyakit jantung koroner (Handajani, 2010).

Tabel 1 menunjukkan bahwa sebagian besar responden berjenis kelamin perempuan yaitu sebanyak 12 orang (60\%). Penelitian Handajani (2010) menyebutkan bahwa pada usia ini perempuan biasanya sedang mencapai puncak karir, dan justru pada masa tersebut mereka akan mengalami menopause (usia 45-55 tahun). Kondisi menopouse dapat menurunkan produksi hormon wanita (estrogen dan progesteron). Dengan penurunannya, maka distribusi lemak tubuh mulai terganggu. Penimbunan lemak yang tidak terdistribusi dengan baik akan mempengaruhi metabolisme tubuh. 
Bila proses ini diikuti dengan pola makan, gaya hidup, dan aktivitas tidak sehat secara berkepanjangan, maka setelah usia 60 tahun individu akan rentan terhadap serangan penyakit degeneratif.

Sebagian besar responden berpendidikan Sekolah Dasar yaitu 9 orang (45\%). Menurut Rahmawati (2016), tingkat pendidikan dapat mempengaruhi kemampuan menerima dan mengolah informasi yang diperoleh menjadi suatu perlakuan yang dapat mempengaruhi kesehatan seseorang. Tingkat pendidikan seseorang dapat mempengaruhi kemampuan mendengar, menyerap informasi, menyelesaikan masalah, perilaku dan gaya hidup. Latar belakang pendidikan akan mempengaruhi pola pikir seseorang tentang kesehatan guna menjaga kesehatannya. Rahmawati (2016) mengemukakan bahwa orang yang mempunyai pendidikan rendah lebih berisiko stroke 6,2 kali dibanding orang yang berpendidikan tinggi.

Tabel 2. Hasil pengukuran kadar kolesterol pada kelompok perlakuan dan kelompok kontrol pre-test dan post-test

\begin{tabular}{|c|c|c|c|c|c|c|c|}
\hline \multirow[t]{2}{*}{$\begin{array}{l}\text { Subyek } \\
\text { Penelitian }\end{array}$} & \multicolumn{2}{|c|}{$\begin{array}{l}\text { Kadar Kolesterol (mg/dL) } \\
\text { Kelompok Perlakuan }\end{array}$} & \multirow[t]{2}{*}{ Selisih } & \multirow[t]{2}{*}{$\begin{array}{c}\text { Subyek } \\
\text { Penelitian }\end{array}$} & \multicolumn{2}{|c|}{$\begin{array}{c}\text { Kadar Kolesterol } \\
\text { (mg/dL) } \\
\text { Kelompok Kontrol }\end{array}$} & \multirow[t]{2}{*}{ Selisih } \\
\hline & Pre Test & Post Test & & & Pre Test & Post Test & \\
\hline 1 & 215 & 190 & -25 & 11 & 227 & 230 & 3 \\
\hline 2 & 218 & 178 & -40 & 12 & 221 & 234 & 13 \\
\hline 3 & 224 & 217 & -7 & 13 & 246 & 250 & 4 \\
\hline 4 & 205 & $205^{*}$ & 0 & 14 & 204 & 206 & 2 \\
\hline 5 & 203 & 194 & -9 & 15 & 210 & $204^{*}$ & -6 \\
\hline 6 & 239 & 161 & -78 & 16 & 215 & 260 & 45 \\
\hline 7 & 256 & 236 & -20 & 17 & 222 & $220^{*}$ & -2 \\
\hline 8 & 225 & 189 & -36 & 18 & 229 & 240 & 11 \\
\hline 9 & 220 & 150 & -70 & 19 & 230 & $223^{*}$ & -7 \\
\hline 10 & 244 & 143 & -101 & 20 & 202 & 208 & 6 \\
\hline Rerata & 224,9 & 186,3 & $-38,6$ & Rerata & 220,6 & 227,5 & 6,9 \\
\hline
\end{tabular}

Tabel 3. Hasil uji normalitas Kadar Kolesterol Darah (KKD) pre-test dan post-test pada kelompok perlakuan dan kelompok kontrol

\begin{tabular}{lcc}
\hline \multicolumn{1}{c}{ Variabel } & Signifikansi Saphiro Wilk & Keterangan \\
\hline Pre-test KKD kelompok perlakuan & 0,808 & Terdistribusi normal \\
Post-test KKD kelompok perlakuan & 0,634 & Terdistribusi normal \\
Pre-test KKD kelompok kontrol & 0,666 & Terdistribusi normal \\
Post-test KKD kelompok kontrol & 0,922 & Terdistribusi normal \\
\hline
\end{tabular}

Sumber: data primer

Tabel 4. Hasil uji statistik paired t-test dan independent t-test Kadar Kolesterol Darah (KKD) pada kelompok perlakuan dan kelompok kontrol

\begin{tabular}{|c|c|c|c|c|c|c|c|}
\hline Uji Statistik & Kelompok & Variabel & Mean & SD & Df & $\begin{array}{c}p- \\
\text { Value }\end{array}$ & Interpretasi \\
\hline \multirow{2}{*}{ Paired t-test } & Perlakuan & $\begin{array}{l}\text { Pre-test KKD } \\
\text { Post-test KKD }\end{array}$ & $\begin{array}{l}186,30 \\
224,90\end{array}$ & 16,921 & 9 & 0,006 & \multirow{2}{*}{$\begin{array}{c}\text { Berbeda } \\
\text { bermakna } \\
\text { Tidak berbeda } \\
\text { NBbermakna }\end{array}$} \\
\hline & Kontrol & $\begin{array}{l}\text { Pre-test KKD } \\
\text { Post-test KKD }\end{array}$ & $\begin{array}{l}227,50 \\
220,60\end{array}$ & 13,385 & 9 & 0,177 & \\
\hline \multirow{2}{*}{$\begin{array}{l}\text { Independent } t \text { - } \\
\text { test }\end{array}$} & \multirow{2}{*}{$\begin{array}{l}\text { Perlakuan } \\
\text { vs Kontrol }\end{array}$} & $\begin{array}{l}\text { Post-test KKD } \\
\text { perlakuan }\end{array}$ & 186,30 & 29,334 & 18 & \multirow{2}{*}{0,002} & \multirow{2}{*}{$\begin{array}{c}\text { Berbeda } \\
\text { bermakna }\end{array}$} \\
\hline & & Post-test KKD kontrol & 227,50 & 18,969 & 18 & & \\
\hline
\end{tabular}

Sumber: data primer 
Berdasarkan tabel 2 didapatkan data bahwa hasil rerata kadar kolesterol darah pre-test kelompok perlakuan sebesar $224,9 \mathrm{mg} / \mathrm{dL}$ dan post-test sebesar $186,3 \mathrm{mg} / \mathrm{dL}$, dimana hasil rerata kadar kolesterol darah tersebut pada saat pre-test cenderung tinggi dibandingkan dengan post-test. Uji statistik (tabel 4) penurunan kadar kolesterol darah dari pre-test ke post-test pada kelompok perlakuan menunjukkan ada nilai beda yaitu $0,006$ ( $\mathrm{p}<0,05)$, dengan rerata penurunan kadar kolesterol darah sebesar $-38,6 \mathrm{mg} / \mathrm{dL}$. Hasil tersebut menunjukkan bahwa secara klinis jus tomat berpengaruh untuk menurunkan kadar kolesterol darah.

Likopen dalam jus tomat mampu menurunkan kadar kolesterol darah melelui beberapa cara yaitu meningkatkan pengambilan dan degradasi LDL oleh makrophag, mencegah aktifitas dari enzim 3-hydroxy-3-methylglutaryl-CoA reductase (HMGKoA reduktase) yang merupakan enzim kunci pada sintesis kolesterol sehingga sintesis kolesterol terhambat, meningkatkan pengaturan reseptor LDL sehingga kadar LDL dalam darah dapat berkurang. 9-oxo-ODA merupakan agonist dari Peroxisome Proliferator-Activated Receptor (PPAR $\alpha$ ) (Preedy dan Waston, 2008).

Berdasarkan hasil penelitian pada tabel 2 menunjukkan bahwa rerata kadar kolesterol darah pada kelompok control, pre-test sebesar $220,6 \mathrm{mg} / \mathrm{dL}$ dan post-test $227,5 \mathrm{mg} / \mathrm{dL}$. Uji statistik penurunan kadar kolesterol darah dari pre-test ke post-test (tabel 3) tidak menunjukkan ada nilai beda yaitu $0,177 \quad(\mathrm{p}>0,05)$, dengan rerata penurunan kadar kolesterol darah sebesar $6,9 \mathrm{mg} / \mathrm{dL}$.

Tidak terjadinya penurunan kadar kolesterol darah pada kelompok kelompok kontrol dipengaruhi oleh faktor genetik (keturunan), aktivitas fisik, gaya hidup (life style). Hal ini sama seperti yang dikemukakan oleh Ferrara et al. (2006) bahwa faktor genetik mempengaruhi penurunan atau peningkatan kadar kolesterol LDL dengan adanya mutasi atau polimorfisme pada gen-gen tertentu juga menjadi penyebab kejadian Penyakit Jantung Koroner (PJK). Faktor genetik digolongkan sebagai faktor yang tidak dapat dikendalikan. Mutasi atau polimorfisme yang terjadi ada akan diwariskan dari satu generasi ke generasi berikutnya. Berdasarkan penelitian, setiap penderita PJK memiliki sekurang-kurangnya dua saudara kandung yang juga menderita PJK.

Studi genomwide linkage menunjukkan adanya lokus pada kromosom 2 yang mempengaruhi risiko atherosklerosis koroner. Selain di kromosom 2, lokus yang terkait dengan risiko PJK juga ditemukan pada kromosom 3,11 dan 17. Dapat disimpulkan bahwa tidak menutup kemungkinan jika dalam silsilah keluarga ada salah satu yang menderita PJK maka keturunan yang lain juga sama.

Penyakit jantung dan stroke dipengaruhi oleh kadar kolesterol yang tinggi. Hal ini didukung oleh pernyataan dari Taqwin (2014) yang menyatakan bahwa kurangnya aktivitas fisik menyebabkan adanya penumpukan jumlah deposit lemak pada dinding pembuluh darah dapat menyebabkan suatu sumbatan pada pembuluh darah atau yang dikenal dengan aterosklerosis. Penelitian ini juga mendukung penelitian dari Tjokroprawiro (2008) yang menyebutkan bahwa pola hidup terdiri atas dua, yakni makan dan gerak. Pola makan kurang sehat terlihat apabila mengonsumsi lemak, kalori, kolesterol, serta kadar gula makanan dalam jumlah berlebih. Menjaga pola makan tidak harus menunggu tua, sebab sejak lahir pola makan sudah mempengaruhi tubuh. Selain pola makan, pola gerak juga mempengaruhi munculnya penyakit degeneratif. Banyaknya kemudahan fasilitas membuat aktivitas fisik jauh berkurang. Kondisi ini akan semakin buruk bila tidak diimbangi dengan olahraga. 
Tabel 5. Hasil pengukuran tekanan darah sistolik pada kelompok perlakuan dan kelompok kontrol pre-test dan post-test

\begin{tabular}{|c|c|c|c|c|c|c|c|}
\hline \multirow[t]{2}{*}{$\begin{array}{l}\text { Subyek } \\
\text { Penelitian }\end{array}$} & \multicolumn{2}{|c|}{$\begin{array}{l}\text { TD Sistolik (mmHg) } \\
\text { Kelompok Perlakuan }\end{array}$} & \multirow[t]{2}{*}{ Selisih } & \multirow[t]{2}{*}{$\begin{array}{c}\text { Subjek } \\
\text { Penelitian }\end{array}$} & \multicolumn{2}{|c|}{$\begin{array}{c}\text { TD Sistolik } \\
\text { (mmHg) } \\
\text { Kelompok Kontrol }\end{array}$} & \multirow[t]{2}{*}{ Selisih } \\
\hline & Pre-test & Post-test & & & Pre-test & Post-test & \\
\hline 1 & 120 & 120 & 0 & 11 & 150 & 140 & -10 \\
\hline 2 & 130 & 110 & -20 & 12 & 139 & 160 & 21 \\
\hline 3 & 130 & 110 & -20 & 13 & 170 & 191 & 21 \\
\hline 4 & 150 & 159 & 9 & 14 & 130 & 120 & -10 \\
\hline 5 & 130 & 120 & -10 & 15 & 145 & 120 & -25 \\
\hline 6 & 172 & 110 & -62 & 16 & 135 & 150 & 15 \\
\hline 7 & 160 & 191 & 31 & 17 & 120 & 155 & 35 \\
\hline 8 & 171 & 130 & -41 & 18 & 150 & 140 & -10 \\
\hline 9 & 117 & 110 & -7 & 19 & 140 & 150 & 10 \\
\hline 10 & 146 & 120 & -26 & 20 & 100 & 120 & 20 \\
\hline Rerata & 142,6 & 128 & $-14,6$ & Rerata & 137,9 & 144,6 & 6,7 \\
\hline
\end{tabular}

Sumber: data primer

Tabel 6. Hasil pengukuran tekanan darah diastolik pada kelompok perlakuan dan kelompok kontrol

\begin{tabular}{|c|c|c|c|c|c|c|c|}
\hline \multirow{3}{*}{$\begin{array}{c}\text { Subyek } \\
\text { Penelitian }\end{array}$} & \multicolumn{6}{|c|}{ pre-test dan post-test } & \multirow{3}{*}{ Selisih } \\
\hline & \multicolumn{2}{|c|}{$\begin{array}{l}\text { TD Diastolik (mmHg) } \\
\text { Kelompok Perlakuan }\end{array}$} & \multirow[t]{2}{*}{ Selisih } & \multirow[t]{2}{*}{$\begin{array}{c}\text { Subyek } \\
\text { Penelitian }\end{array}$} & \multicolumn{2}{|c|}{$\begin{array}{c}\text { TD Diastolik } \\
\text { (mmHg) Kelompok } \\
\text { Kontrol }\end{array}$} & \\
\hline & Pre-Test & Post-Test & & & Pre-Test & Post-Test & \\
\hline 1 & 80 & 80 & 0 & 11 & 70 & 80 & 10 \\
\hline 2 & 80 & 70 & -10 & 12 & 75 & 100 & 25 \\
\hline 3 & 80 & 70 & -10 & 13 & 110 & 109 & -1 \\
\hline 4 & 100 & 114 & -14 & 14 & 80 & 80 & 0 \\
\hline 5 & 80 & 80 & 0 & 15 & 85 & 80 & -5 \\
\hline 6 & 92 & 70 & -22 & 16 & 75 & 100 & 25 \\
\hline 7 & 90 & 109 & 19 & 17 & 80 & 85 & 5 \\
\hline 8 & 73 & 80 & 7 & 18 & 100 & 80 & -20 \\
\hline 9 & 72 & 70 & -2 & 19 & 90 & 100 & 10 \\
\hline 10 & 73 & 70 & -3 & 20 & 70 & 80 & 10 \\
\hline Rerata & 82 & 81,3 & $-0,7$ & Rerata & 83,5 & 89,4 & 5,9 \\
\hline
\end{tabular}

Sumber: data primer

Tabel 7. Hasil uji normalitas tekanan darah sistolik dan diastolik pre-test dan post-test pada kelompok perlakuan dan kelompok kontrol

\begin{tabular}{lcl}
\hline \multicolumn{1}{c}{ Variabel } & Signifikansi Saphiro Wilk & \multicolumn{1}{c}{ Keterangan } \\
\hline pre-test Sistolik kelompok perlakuan & 0,275 & Terdistribusi normal \\
post-test Sistolik kelompok perlakuan & 0,002 & Tidak terdistribusi normal \\
pre-test Diastolik kelompok perlakuan & 0,129 & Terdistribusi normal \\
post-test Diastolik kelompok perlakuan & 0,001 & Tidak terdistribusi normal \\
pre-test Sistolik kelompok kontrol & 0,824 & Terdistribusi normal \\
post-test Sistolik kelompok kontrol & 0,218 & Terdistribusi normal \\
pre-test Diastolik kelompok kontrol & 0,189 & Terdistribusi normal \\
post-test Diastolik kelompok kontrol & 0,006 & Tidak terdistribusi normal \\
\hline
\end{tabular}

Sumber: data primer 
Tabel 8. Hasil uji statistik wilcoxon dan paired t-test tekanan darah pada kelompok perlakuan dan kelompok kontrol

\begin{tabular}{|c|c|c|c|c|c|c|c|}
\hline Uji Statistik & Kelompok & Variabel & Mean & SD & $\mathbf{Z} / \mathbf{t}$ & $\begin{array}{c}p- \\
\text { Value }\end{array}$ & Interpretasi \\
\hline \multirow{4}{*}{ Wilcoxon } & \multirow{4}{*}{ Perlakuan } & pre-test Sistolik & 142,60 & 20,228 & 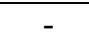 & \multirow{2}{*}{0,109} & \multirow{4}{*}{$\begin{array}{l}\text { Tidak berbeda } \\
\text { bermakna } \\
\text { Tidak berbeda } \\
\text { bermakna }\end{array}$} \\
\hline & & post-test Sistolik & 128,00 & 26,712 & 1,601 & & \\
\hline & & $\begin{array}{l}\text { pre-test } \\
\text { Diastolik }\end{array}$ & 82,00 & 9,226 & & \multirow{2}{*}{0,779} & \\
\hline & & $\begin{array}{l}\text { post-test } \\
\text { Diastolik }\end{array}$ & 81,30 & 16,600 & 0,280 & & \\
\hline Paired t-test & \multirow{3}{*}{ Kontrol } & $\begin{array}{l}\text { pre-test Sistolik } \\
\text { post-test } \text { Sistolik }\end{array}$ & $\begin{array}{l}137,90 \\
144,60\end{array}$ & $\begin{array}{l}18,876 \\
22,147\end{array}$ & 1,105 & 0,298 & $\begin{array}{l}\text { Tidak berbeda } \\
\text { bermakna }\end{array}$ \\
\hline \multirow{2}{*}{ Wilcoxon } & & $\begin{array}{l}\text { pre-test } \\
\text { Diastolik }\end{array}$ & 83,50 & 13,134 & \multirow{2}{*}{1,429} & \multirow{2}{*}{0,153} & \multirow{2}{*}{$\begin{array}{c}\text { Tidak berbeda } \\
\text { bermakna }\end{array}$} \\
\hline & & post-test Sistolik & 137,90 & 18,876 & & & \\
\hline
\end{tabular}

Sumber: data primer

Tabel 9. Hasil uji statistik mann whitney selisih rerata tekanan darah sistolik dan diastolik pada kelompok perlakuan dan kelompok kelompok kontrol

\begin{tabular}{lccccc}
\hline \multicolumn{1}{c}{ Variabel } & Mean & SD & Z & p-Value & Interpretasi \\
\hline post-test TD sistolik & 136,30 & 25,355 & $-1,925$ & 0,054 & Tidak berbeda bermakna \\
post-test TD diastolik & 85,35 & 14,492 & $-1,815$ & 0,070 & Tidak berbeda bermakna \\
\hline Sumber: data primer & & & & &
\end{tabular}

Hasil penelitian (tabel 9) menunjukkan tidak adanya pengaruh signifikan dari pemberian jus tomat terhadap perubahan tekanan darah sistolik $(\mathrm{p}=0,054)$ dan tekanan darah diastolik $(\mathrm{p}=0,070)$ pada responden dewasa di Dusun Ngrame Tamantirto Yogyakarta. Pemberian jus tomat mampu menurunkan rata-rata tekanan darah sistolik hingga $-14,6 \mathrm{mmHg}$ dan tekanan darah diastolik hingga $-0,70 \mathrm{mmHg}$ pada kelompok perlakuan (tabel 5). Sementara itu pada kelompok kontrol yang tidak menerima perlakuan, tidak ditemukan adanya perbedaan tekanan darah sistolik dan diastolik, justru terjadi peningkatan rerata $6,7 \mathrm{mmHg}$ pada tekanan sistolik dan 5,9 $\mathrm{mmHg}$ (tabel 6) pada tekanan diastolik (tabel 7). Tidak adanya perbedaan bermakna pada responden kelompok perlakuan dikarenakan ada 2 responden yang memiliki peningkatan tekanan darah sistolik setelah perlakuan dan 1 orang responden yang tetap tekanan darahnya tetap. Sedangkan pada tekanan darah diastolik, terdapat 3 responden yang mengalami peningkatan dan 1 responden yang tetap.

Hasil penelitian ini bertentangan dengan hasil penelitian Kailaku, Dewandari, dan Sunarmani (2007), yang juga menemukan adanya pengaruh signifikan dari pemberian jus tomat terhadap penurunan tekanan darah sistolik dan diastolik pada perempuan postmenopause. Pada penelitian Gajendragadkar et al. (2014), jus tomat dapat memberikan efek penurunan tekanan darah sistolik hingga $-11,76 \mathrm{mmHg}$ dan penurunan tekanan darah diastolik hingga $-8,82 \mathrm{mmHg}$.

Beberapa dugaan yang mampu menjelaskan mengapa tekanan darah sistolik dan diastolik pada kelompok perlakuan yang pertama adalah pemberian jus tomat baru dilakukan selama 14 hari. Penelitian yang dilakukan oleh Bhowmik et al (2012) menyebutkan bahwa pemberian tomat sebanyak $200 \mathrm{gr} / \mathrm{hari}$ mampu menurunkan tekanan darah setelah diberikan selama 3-6 minggu. Tomat dapat menurunkan tekanan darah karena tomat kaya akan kandungan kalium, flavonoid, likopen yang dikenal dapat menurunkan tekanan darah. Kalium dalam tomat memiliki khasiat diuretik sehingga konsumsi tomat yang kaya akan kalium akan meningkatkan retensi natrium, hal tersebut 
dapat membantu menurunkan tekanan darah. Kalium juga berguna untuk menghambat renin sehingga dalam sistem renin angiotensin, agiotensinogen tidak dapat diubah menjadi angiotensin I. Tekanan darah sistolik berkurang $0,9 \mathrm{mmHg}$ dan diastolik dapat berkurang $0,8 \mathrm{mmHg}$ jika asupan kalium mencapai $1000 \mathrm{mg}$ per hari. Efek antihipertensif kalium dilakukan melalui beberapa mekanisme yaitu natriuresis, menghambat reabsorpsi natrium di tubulus renal proksimal dan menekan sekresi renin, menormalkan kadar substansi digitalis plasma, meningkatkan volume ekskresi urin, relaksasi otot halus melalui produksi oksida nitrat, menekan pembentukan radikal bebas, dan melindungi pembuluh darah dari luka akibat hipertensi (Chauhan et al., 2011).

Alasan kedua,disebabkan karena responden tidak dikelola dietnya. Hal ini disebabkan peneliti lebih berfokus pada pencarian responden dengan kadar kolesterol yang tinggi, bukan pada tekanan darahnya yang tinggi. Karena rerata tekanan darah responden normal tinggi, sehingga responden tidak dilakukan pengendalian diet rendah garam. Menurut Lorenz et al (2012), bahwa penatalaksanaan hipertensi dapat dilakukan secara farmakologi dan non-farmakologi. Penatalaksanaan farmakologi menggunakan obat-obatan anti hipertensi, penatalaksanaan non-farmakologi meliputi penurunan berat badan untuk responden yang obesitas, diet sesuai anjuran DASH (Dietary Approach to Stop Hypertention), diet rendah garam, dan meningkatkan aktivitas fisik.

Alasan ketiga, faktor yang mempengaruhi tekanan darah ada beberapa macam. Salah satunya adalah stres. Penelitian ini tidak mampu mengkondisikan pasien terhindar dari stres, baik stres individu maupun stres dari lingkungannya. Hubungan antara tingkat stres dengan tekanan darah diduga melalui aktivitas saraf simpatis, yang dapat meningkatkan tekanan darah secara bertahap. Stres atau ketegangan jiwa (rasa tertekan, murung, bingung, cemas, berdebar-debar, rasa marah, dendam, rasa takut dan rasa bersalah), dapat merangsang kelenjar anak ginjal melepas hormon adrenalin dan memacu jantung berdenyut lebih cepat serta lebih kuat, sehingga tekanan darah akan meningkat (Mike \& Kravitz, 2010).

Penderita hipertensi yang mendapatkan penatalaksanaan hipertensi atau tidak, cenderung memiliki tekanan darah yang tinggi meski ada kalanya tekanan darah berada dalam batas normal. Kondisi akan diperburuk dengan adanya peningkatan tekanan darah akibat stres, maka tekanan darah akan menjadi semakin tinggi. Apabila kondisi ini terjadi terus menerus dalam waktu yang lama tanpa penanganan yang tepat maka tekanan darah tinggi tersebut akan sulit dikontrol. Tekanan darah yang tidak terkontrol, akan menjadikan penyebab utama penyakit stroke (Prasetyorini, 2012).

\section{SIMPULAN}

Hasil penelitian menunjukkan terdapat perbedaan bermakna kadar kolesterol darah responden pada kelompok kontrol maupun kelompok perlakuan setelah pemberian jus tomat 14 hari $(p=0,006)$, namun tidak terdapat perbedaan bermakna tekanan darah baik sistolik $(p=0,054)$ maupun diastolik $(p=0,070)$ pada kelompok kontrol dan kelompok perlakuan setelah pemberian jus tomat selama 14 hari.

\section{SARAN}

Untuk mendapatkan hasil maksimal, sebaiknya responden mengkonsumsi jus tomat selama minimal 3-6 minggu. 


\section{DAFTAR PUSTAKA}

Anggraeni, IP., Rosalina., Aniroh, U. (2014). Pengaruh Pemberian Jus Tomat Terhadap Kadar Kolesterol Dalam Darah Pada Pasien Hiperkoleterolemia Di Puskesmas Bergas Kabupaten

Semarang, (perpusnwu.web.id/karyailmiah/documents/4216.docx), diakses tanggal 14 Agustus 2016.

Anwar, TB. (2004). Dislipidemia Sebagai Faktor Risiko Penyakit Jantung Koroner. $e$ USU Resipository.1-10.

Bhowmik, D., Kumar, KPS., Pasman, S., Srivastava, S. (2012). Tomato-a natural medicine and its health benefits. Phytojournal, 1: 33-43.

Chauhan, K., Sharma, S., Agarwal, N., Chauhan, B. (2011). Lycopene of tomato fame: its role in health and disease. IJPS, 10 (1): 100-115.

Dwijayanthi, L. (2011). Edisi 2 Ilmu Gizi Menjadi Sangat Mudah. Jakarta: EGC.

Erejuwa, OO. (2014). Effect of honey in diabetes mellitus: matters arising. J Diabetes Metab Disord. 13 (23): 1-4.

Ferrara, LA., Guida, L., Iannuzzi, R., Celentano, A., Lionello, F. (2002). Serum cholesterol affects blood pressure regulation. J Hum Hypertens. 16: 337-343.

Gajendragadkar, PR., Hubsh, A., Mäki-Petäjä, KM., Serg, M., Wilkinson, IB., Cheriyan, J. (2014). Effects of oral lycopene supplementation on vascular function in patients with cardiovascular disease and healthy volunteers: a randomised controlled trial. PLoS One, 9 (6): 1-13.

Handajani, A. (2010). Faktor-Faktor Yang Berhubungan Dengan Pola Kematian Pada Penyakit Degeneratif Di Indonesia. Buletin penelitian sistem kesehatan, 13 (1).

Kailaku, SI., Dewandari, KT., Sunarmani. (2007). Potensi likopen dalam tomat untuk kesehatan. Buletin Teknologi Pascapanen Pertanian, 3: 50-58.

Li, X., Xu, J. (2013). Lycopene supplement and blood pressure: an updated metaanalysis of intervention trials. Nutrients, 5: 3696-3712.

Lorenz, M., Fechner, M., Kalkowski, J., Fröhlich, K., Trautmann, A., Böhm, V., Liebisch, G., Lehneis, S., Schmitz, G., Ludwig, A., Baumann, G., Stangl, K., Stangl, V. (2012). Effects of lycopene on the initial state of atherosclerosis in New Zealand White (NZW) rabbits. PLoS One, 7 (1): 1-8.

Margarita, Y., Princen., Andi., Rumawas, ME., Kidarsa, VB., Sutrisna, B. (2013). Kadar kolesterol total dan tekanan darah orang dewasa Indonesia. Kemas, 8 (2): 79-84.

Mike, JN., Kravitz, L. (2010). Important risk factor and fitness assessment "numbers". IDEA Fitness Journal, 7 (11).

Nasution, LS. (2013). Pengaruh pemberian likopen terhadap perkembangan lesi aterosklerotik pada tikus hiperkolesterolemia. Jurnal Kedokteran dan Kesehatan. 9 (1): 5-9.

Navarro-González, I., Pérez-Sánchez, H., Martín-Pozuelo, G., García-Alonso, J., Periago, MJ. (2014). The inhibitory effects of bioactive compounds of tomato juice binding to hepatic HMGCR: in vivo study and molecular modelling. PLoS One. 9 (1): 1-11.

Palozza, P., Catalano, A., Simone, RE., Mele, MC., Cittadini, A. (2012). Effect of lycopene and tomato products on cholesterol metabolism. Ann Nutr Metab. 61: 126-134. 
Prasetyorini, HT., Prawesti, D. (2012). Stres pada Penyakit terhadap Kejadian Komplikasi Hipertensi pada Pasien Hipertensi.(http://download.portalgaruda.org /article.php?article=4235\&val=360), diakses tanggal 24 September 2016.

Preedy, V., Waston, RR. (2008). Tomatoes and Tomato Product Nutritional Medical and Therapeutic Properties, (www.googlebook.com), diakses tanggal 13 Juli 2016.

Rachmawati, E. (2016). Hubungan Antara Usia, Jenis Kelamin, Pendapatan, Pendidikan, Kebiasaan Merokok, Asupan Makanan Dan Stres Dengan Risiko Stroke Iskemik Di Kabupaten Kudus. Disertasi. Universitas Sebelas Maret.

Ried, K., Fakler, P. (2011). Review. Protective effect of lycopene on serum cholesterol and blood pressure: Meta-analyses of intervention trials. Maturitas, 68: 299-310.

Samson, S., Mundkur, L., Kakkar, VV. (2012). Review article: immune response to lipoproteins in atherosclerosis. Cholesterol, 1-12.

Seprianti. (2011). Pengaruh latihan fisik terstruktur terhadap High Density Lipoprotein (HDL) pada pasien hipertensi di poliklinik ginjal dan hipertensi RSUP M Djamil Padang. Naskah publikasi. Universitas Andalas.

Taqwin RM. (2014). Uji Efek Ekstrak Etanol 70\% Daging Buah Asam Jawa (Tamarindus indical) Terhadap Penurunan Kadar Kolesterol Total Dan Trigliserida Pada Tikus Putih Jantan (Rattus Norvegicus) Galur Wistar Dengan Dislipidemia. Skripsi. Tidak dipublikasikan.

Tjokroprawiro A. (2008). Hindari Penyakit Degeneratif dengan Pola Hidup Sehat, Awas Lingkar Pinggang Besar, (www.indopos.co.id), diakses tanggal 21 September 2016. 